\title{
'Li bons dus de Buillon': Genre conventions and the depiction of Godfrey of Bouillon in the Chanson d'Antioche and the Chanson de Jérusalem ${ }^{1}$
}

\section{Simon John (Swansea University)}

The First Crusade (1095-99) exerted a profound cultural impact in Latin Christendom in the Middle Ages. Even before its forces had captured Jerusalem in July 1099, written reports and spoken traditions concerning the expedition had begun to circulate in the West, and both continued to do so in the centuries that followed. ${ }^{2}$ As a result of this process, many

\footnotetext{
${ }^{1}$ In this essay, the following abbreviations are used:
}

ChAnt: La Chanson d'Antioche, ed. S. Duparc-Quioc, 2 vols, Documents relatifs à l'histoire des croisades publiés par l’Académie des Inscriptions et Belles-Lettres, vol. 11 (Paris, 1977-8), tr. in The Chanson d'Antioche: An Old French Account of the First Crusade, tr. S. Edgington and C. Sweetenham, Crusade Texts in Translation, vol. 22 (Farnham, 2011).

Chétifs = La Chanson des Chétifs, ed. G. M. Myers, OFCC, vol. 5, tr. in The Chanson des Chétifs and Chanson de Jérusalem: Completing the Central Trilogy of the Old French Crusade Cycle, tr. C. Sweetenham, Crusade Texts in Translation, vol. 29 (Farnham, 2016), pp. 67-172,

ChJér = La Chanson de Jérusalem, ed. N. R. Thorp, OFCC, vol. 6, tr. in Chanson des Chétifs and Chanson de Jérusalem: tr. Sweetenham, pp. 173-353.

OFCC = The Old French Crusade Cycle, ed. E.J. Mickel and J.A. Nelson, 10 vols. in 11 (Tucsaloosa, 19772003).

\footnotetext{
${ }^{2}$ C. Sweetenham, 'What Really Happened to Eurvin de Créel’s Donkey? Anecdotes in Sources for the First Crusade’, in M. Bull and D. Kempf (eds), Writing the Early Crusades: Text, Transmission and Memory
} (Woodbridge, 2014), pp. 75-88; S. John, 'Historical Truth and the Miraculous Past: The Use of Oral Evidence in Twelfth-Century Historical Writing on the First Crusade', in English Historical Review, vol. 130, no. 543 
of the expedition's participants - particularly its leaders - acquired great renown in Europe. Stories of their deeds were told and retold in the ensuing years, decades and centuries. Godfrey of Bouillon, the prominent leader who was appointed to rule the nascent state of Jerusalem soon after the Holy City’s capture, became the nexus of a particularly rich constellation of traditions after his death in $1100 .{ }^{3}$ By the turn of the fourteenth century, Godfrey had been transformed into an icon of the First Crusade, and of crusading more generally. It was the symbolic status that Godfrey had acquired by about 1300 that adduced Dante to include Godfrey as a 'warrior of the faith' in the Divine Comedy, and established the conditions in which Godfrey was enrolled into the roster of chivalric heroes known as the 'Nine Worthies'. ${ }^{4}$ This essay will consider an important dynamic of the process through which Godfrey was metamorphosed into a figure who by the end of the thirteenth century had come to embody aristocratic ideas and expectations.

Medieval traditions pertaining to the memory of Godfrey and the First Crusade took several different forms. From the first years of the twelfth century, a range of authors produced full-length narrative accounts of the expedition, working predominantly in Latin prose. ${ }^{5}$ Alongside this surge in Latin historiography, there also took shape a body of vernacular rhymed songs concerning the First Crusade. At some point, these songs were

(2015), 263-301. On the First Crusade, see: J. France, Victory in the East: A Military History of the First Crusade (Cambridge, 1994).

${ }^{3}$ S. John, Godfrey of Bouillon: Duke of Lower Lotharingia, Ruler of Latin Jerusalem, c.1060-1100, Rulers of the Latin East, vol. 2 (Abingdon, 2018).

${ }^{4}$ John, Godfrey of Bouillon, pp. 227-53, discusses the development of Godfrey’s posthumous reputation in the twelfth an thirteenth centuries, and his incarnations in the Divine Comedy and as one of the 'Nine Worthies'. ${ }^{5}$ S. Edgington, 'Reviewing the Evidence', in J. Phillips (ed.), The First Crusade: Origins and Impact (Manchester, 1997), pp. 57-77; W. Purkis, 'Rewriting the History Books: The First Crusade and the Past', in Bull and Kempf (eds), Writing the Early Crusades, pp. 116-26. 
given the form of Old French chansons de geste. ${ }^{6}$ These crusade chansons probably existed in the twelfth-century only as oral texts, and were only compiled into written form in the thirteenth century. ${ }^{7}$ This body of chansons - known as the Crusade Cycle - collectively advances an embroidered and at points purely fictional rendition of the origins, history and aftermath of the First Crusade, conveying a narrative that is infused with the ethos of the martial aristocracy. ${ }^{8}$ At the heart of the Crusade Cycle is a central trilogy of songs - the Chanson d'Antioche, the Chanson des Chétifs and the Chanson de Jérsualem - known as the 'cycle rudimentaire'. ${ }^{9}$ The extant versions of this central trilogy were probably consolidated into their extant form in the late twelfth or early thirteenth century. ${ }^{10}$ The Chanson d'Antioche focuses on the origin of the First Crusade and covers the expedition through to the aftermath of the capture of Antioch. The Jérusalem picks the narrative of the First Crusade up where the Antioche left off, covering the crusaders’ attack on the Holy City, the appointment of Godfrey as its ruler, and the efforts by the crusaders to defend the city. Les Chétifs, whose

\footnotetext{
${ }^{6}$ C. M. Jones, An Introduction to the Chansons de Geste, New Perspectives on Medieval Literature: Authors and Traditions (Gainesville, 2014).

${ }^{7}$ On the manuscripts of the cycle, see the essay by G. M. Myers in OFCC, vol. 1, pp. xiii-lxxxviii

${ }^{8}$ For a starting point, see: K.-H. Bender, and H. Kleber, Le Premier Cycle de la Croisade. De Godefroy à Saladin: entre la chronique et la conte de fees (1100-1300), Grundriss der romanischen Literaturen des Mittelalters III, Les Epopées romanes, Tome I/II, fascicule 5 (Heidelberg, 1986).

9 The essay will draw from the edition of the Antioche by Duparc-Quioc and the translation by Edgington and Sweetenham, and the edition of the Jérusalem by Thorp and the translation of it by Sweetenham (see footnote 1, above). The footnotes will each contain two page citations: the first to the edition, the second to the translation. ${ }^{10}$ On the composition and date of the 'cycle rudimentaire', see Chanson d'Antioche, tr. Edgington and Sweetenham, pp. 3-48.
} 
events purport to have taken place between those of the Antioche and the Jérusalem, tells of the adventures of a trio of captured crusaders in the service of a Muslim potentate. ${ }^{11}$

Taking the Crusade Cycle as a whole, Godfrey functions as its main protagonist. This was an outcome of the way in which the cycle developed over time. ${ }^{12} \mathrm{~A}$ branch of the cycle probably composed in the first part of the thirteenth century to extend the narrative of the 'cycle rudimentaire' back in time recounts a fictionalised and at points fantastical version of the history of Godfrey's family and exploits before the First Crusade, casting him as the scion of the legendary warrior known as the Swan Knight. A further body of late thirteenth-century songs pick up the narrative as it ended at the conclusion of the Chanson de Jérusalem to recount stories relating to the reigns of Godfrey’s successors in the Holy City. Yet, a critical reading of the Antioche and Jérusalem in isolation from the remainder of the cycle indicates that Godfrey is not the unalloyed hero of these songs. The other chief participants in the First Crusade are depicted in similarly exalted light. Indeed, references to Bohemond in the Antioche even outnumber those to Godfrey. In short, then, Godfrey was moulded into the main character of the Crusade Cycle through the addition of the chansons which focus on his

\footnotetext{
${ }^{11}$ P. Péron, 'La croisade des “chétifs”: tradition et renouvellement de la perspective épique’, in Romania, vol. 125, no. 497-8 (2007), 87-117.

${ }^{12}$ For comments on the depiction of Godfrey and his family in the Crusade Cycle, see: D. A. Trotter, 'L’ascendance mythique de Godefroy de Bouillon et le Cycle de la Croisade’, in L. Harf-Lancner (ed.), Métamorphose et bestiaire fantastique au moyen âge (Paris, 1985), pp. 107-35; S. John, ‘Godfrey of Bouillon and the Swan Knight', in S. John and N. Morton (eds), Crusading and Warfare in the Middle Ages: Realities and Representations. Essays in Honour of John France, Crusades Subsidia 7 (Farnham, 2014), pp. 129-42; G. H. M. Claassens, 'De Zwaanridder en Nijmegen. Brabantse politiek in de literatuur’, in Jaarboek Numaga, vol. 38 (1991), 19-40.
} 
ancestry and early life and those which purport to recount the deeds of his successors in Jerusalem. ${ }^{13}$

Unlike texts such as the Chanson de Roland and the other chansons de geste devoted to Charlemagne and his family and associates, which were composed three or four centuries after the events they purported to recount, the Crusade Cycle started to take shape within only about a century - perhaps three or four generations - of the First Crusade. Moreover, there are clear synergies between the extant versions of the chansons embedded in the Crusade Cycle and the Latin prose chronicles of the expedition. ${ }^{14}$ While it may thus be tempting to mine these chansons for information about the historical crusade, and the activities of its participants, this is a temptation that is firmly to be resisted. By means of an analysis of the depiction of Godfrey of Bouillon in the Chanson d'Antioche and the Chanson de Jérusalem, the main songs of the 'cycle rudimentaire', and thus of the Crusade Cycle as a whole, and drawing from the work of scholars such as Noble and Hanley on the expectations and literary tropes which shaped the portrayals of main characters in the chansons de geste, this essay aims to show that the controlling principles which underpinned the depiction of Godfrey in these texts were the genre conventions of the chansons. ${ }^{15}$ In short, these texts tell us nothing

\footnotetext{
${ }^{13}$ John, 'Godfrey of Bouillon and the Swan Knight'.

${ }^{14}$ See, for instance: S. Edgington, 'Albert of Aachen and the Chansons de Geste', in John France and William G. Zajac (eds), The Crusades and Their Sources: Essays Presented to Bernard Hamilton (Aldershot, 1998), pp. 23-37; F. Andrei, ‘Alberto di Aachen e la Chanson de Jérusalem', Romance Philology, vol. 63, no. 1 (2009), 169; N. Thorp, 'La Chanson de Jérusalem and the Latin Chronicles', in P. E. Bennett, A. E. Cobby and J. E. Everson (eds), Epic and Crusade: Proceedings of the Colloquium of the Société Rencesvals British Branch held at Lucy Cavendish College, Cambridge, 27 - 28 March 2004 (Edinburgh, 2006), pp. 153-71.

${ }^{15}$ C. Hanley, War and Combat: 1150-1270: The Evidence from Old French Literature (Cambridge, 2003); P. Noble, 'Military Leadership in the Old French Epic', in M. Ailes, P. E. Bennett and K. Pratt (eds), Reading around the Epic: A Festschrift in Honour of Professor Wolfgang Van Emden (London, 1998), pp. 171-91; A. Leclercq, Portraits croisés: l'image des France et des Musulmans dans les textes sur la Premiere Croisade,
} 
about the 'real' crusade, but instead give insight into how the memory of the expedition was shaped by aristocratic expectations concerning the heroes of the chansons de geste. It will be suggested that the Antioche and the Jérusalem are typical of the chansons in the sense that they utilise a variety of narrative strategies designed to present their protagonists in a particular light.

The essay has three lines of enquiry in respect of the presentation of Godfrey in the Antioche and the Jérusalem. Firstly, it will explore the emphasis placed on Godfrey’s noble character, reputation and lineage. Secondly, it will consider the ways in which the songs accentuate his prowess as a man of war, Thirdly, it will interrogate the methods used to portray him as a man devoted to the Christian faith. The essay will not consider every single reference to Godfrey in the texts, but it will draw from representative examples. It should be pointed out that in many of the instances in which Godfrey is referred to, the precise word formation seems to have been principally determined by the metre and rhyming scheme of the particular verse (laisse) in which the reference appears. Nevertheless, this supports the overarching argument of this essay: that the conventions of the genre play a key role in how Godfrey is portrayed in the Antioche and the Jérusalem.

Nobility was a key characteristic of the heroes of chansons de geste. ${ }^{16}$ Throughout the two chansons under consideration here, Godfrey is repeatedly ascribed with noble characteristics. He is habitually referred to with an epithet or short phrase intended to underline his personal qualities. Hence, he is referred to in the Antioche in terms such as 'the Chroniques latines et araves, chansons de geste françaises des XIIe et XIIIe siècles, Nouvelle Bibliothèque du Moyen Âge, vol. 96 (Paris, 2010).

${ }^{16}$ As the aptly-named Noble put it, the leading protagonists are 'all...noble and most of them of the highest nobility’. Noble, ‘Military Leadership’, pp. 179-81. Cf. Hanley, War and Combat, p. 130: ‘the principal chivalric attributes are status and prowess'. 
good duke Godfrey’ (li bons dus Godefois) ${ }^{17}$, 'the eminent Godfrey’ (Godefrois qui tant fait a loer $)^{18}$, the 'lion-hearted duke' (li dus...qui cue rot de lyon). ${ }^{19}$ Likewise, in the Jérusalem he is variously referred to with closely-related terms such as 'the good duke' (li bons dus) ${ }^{20}$ or 'the good Duke of Bouillon' (li bons dus de Buillon). ${ }^{21}$ A quality that is consistently imputed to Godfrey in these songs is that of bravery. This is perhaps to be expected, since personal courage was an essential attribute for the heroes of the chansons. ${ }^{22}$ Hence, in the Antioche, he is described as 'the brave Godfrey of Bouillon' (Godefrois de Buillon li hardis) $)^{23}$ and 'the brave-faced Godfrey' (Godefrois... a le ciere hardie). ${ }^{24}$ Similarly, the Jérusalem refers to Godfrey as 'lion-hearted' (cuer ot de lion) ${ }^{25}$, 'valiant' (Godefroi qui molt a hardement $)^{26}$, and asserts that he 'had the courage of a wild boar' (cuer ot de sengler). ${ }^{27} \mathrm{~A}$ brief reference to Godfrey in the Chétifs ascribes similar qualities (Godefrois a le chiere hardie). ${ }^{28}$ The Antioche and the Jérusalem also emphasise Godfrey’s courage by according him particular feats of bravery. In addition to his various feats in battle (which are discussed in more detail below), it is recounted in the Antioche Godfrey was chosen to be the crusaders'

\footnotetext{
${ }^{17}$ ChAnt, $1.94 / 144$.

${ }^{18}$ ChAnt, 1.114/154.

${ }^{19}$ ChAnt, 1.158/172.

${ }^{20}$ ChJér, 104/232.

${ }^{21}$ ChJér, 111/238.

${ }^{22}$ Noble, ‘Military Leadership’, pp. 176-9.

${ }^{23}$ ChAnt, 1.191/187.

${ }^{24}$ ChAnt, 1.161/224.

${ }^{25}$ ChJer, 93/223.

${ }^{26}$ ChJér, 125/250.

${ }^{27}$ ChJér, 82/214.

${ }^{28}$ Chétifs, 3/67.
} 
champion in an episode of single combat in part because of his bravery. ${ }^{29}$ His courage is depicted in contexts other than the battlefield; in one passage in the Antioche, Godfrey volunteers to keep guard over the crusader camp during the night, with only his own horse for company. The Jérusalem attributes him with a similar action. ${ }^{30}$

Heroes of chansons also possessed exemplary reputations. Both songs under consideration in this essay thus seek to convey the sense that Godfrey had earned repute for carrying out noteworthy deeds. The very first reference to him in the Antioche casts him as a man 'with many achievements to his credit' (Godefroid ki molt fist a proisier). ${ }^{31}$ In another passage, he is described simply as 'renowned' (Godefrois l'alosés). ${ }^{32}$ Similarly, at one point in the Jérusalem, he is described as 'renowned for his achievements' (a la chiere menbree). ${ }^{33}$ In one of the few references to Godfrey in the Chétifs, he is called 'that author of noble deeds Duke Godfrey’ (Godefroi, qui tant fait a douter).${ }^{34}$ At the point in the Jérusalem in which Godfrey is appointed 'king' of Jerusalem, it is related that he was 'the best knight who ever put on a sword' (Del mellor chevalier qui ainc çainsist d'espee). ${ }^{35}$

Another important element in the depiction of heroes in the chansons is their lineage and family. ${ }^{36}$ A significant passage in the Antioche is devoted specifically to Godfrey’s ancestry. In that passage, Godfrey is chosen as the crusaders' champion in single combat in

\footnotetext{
${ }^{29}$ ChAnt, 1.371/277.

${ }^{30}$ ChAnt, 1.157-8/172; ChJér, 29/190.

${ }^{31}$ ChAnt, 1.21/102.

${ }^{32}$ ChAnt, 1.63/129.

${ }^{33}$ ChJér, 140/161.

${ }^{34}$ Chétifs, $12 / 75$.

${ }^{35}$ ChJér, 152/272.

${ }^{36}$ Noble, ‘Military Leadership’, p. 175.
} 
part because of his descent from Charlemagne ( $k$ 'il est...del linage Carlon). ${ }^{37}$ The ensuing verse then sets out in detail his proud lineage, pinpointing his descent from the legendary warrior known as the Swan Knight. ${ }^{38}$ His connection to the Swan Knight is also referenced twice in the Jérusalem. ${ }^{39}$ In line with this focus on Godfrey’s lineage are repeated instances in which Godfrey is explicitly connected to his brothers, Baldwin and Eustace, who are also presented in positive terms. At one point the Antioche refers to Eustace as 'the brother of the duke of Bouillon' (frere al duc de Bullon) ${ }^{40}$, while the Jérusalem calls Baldwin the same (frere au duc de Bullon). ${ }^{41}$ One short laisse of the Antioche is devoted specifically to recounting a feat of arms carried out in one battle by Baldwin, closely followed by a deed enacted by Eustace. ${ }^{42}$ In one military encounter related in the Jérusalem, Baldwin is described as declaiming that he was 'the brother of the valiant Duke Godfrey and the noblehearted Count Eustace' (Frere au duc Godefroi qui molt a hardement/ Et le conte Ewistace qui molt a le cors gent). ${ }^{43}$ In several instances in the Jérusalem, the three brothers are depicted acting - and often fighting - alongside one another. In one battle, for instance, the three brothers invoke Christ whilst swearing in unison that they would rather be decapitated than retreat even the length of a lance. ${ }^{44}$ At another point, Godfrey calls out to his two brothers amidst a battle to encourage them: 'What are you playing at brothers? Come on, don't act like cowards. We are reputed to be the bravest in God's army: do not fear death, go

\footnotetext{
${ }^{37}$ ChAnt, $1.371 / 277$.

${ }^{38}$ ChAnt, $1.371-3 / 277-8$.

${ }^{39}$ ChJér, 212/ 318, 224/328.

${ }^{40}$ ChAnt, 1.307/248.

${ }^{41}$ ChJér 64/199.

${ }^{42}$ ChAnt, $1.85-6 / 140$.

${ }^{43}$ ChJér, 135/150.

${ }^{44}$ ChJér, 164/281.
} 
out and seek it!' (Que faites vos, mi frere? Ne vos alés faignant!/ On dist que de l'ost Deu estiemes mius Vaillant./ Ne dotes pas le mort mais alés le querent!). ${ }^{45}$

Another strategy employed to impute the connected qualities of lineage and nobility to Godfrey is apparent in passages in which he is depicted as a man who was concerned with these qualities in others. In the Antioche, Godfrey at one point greets William of Grandmesnil thusly: 'How are thing with you, noble baron's son?' (Comment avés erré, gentius fils a baron?). ${ }^{46}$ At another point, Godfrey is depicted commenting on a seneschal who had distinguished himself in one military engagement that, in the light of his exploits, 'he can be knighted whenever he wants' (Quele hore qu'il vaurra chevalier en feron). ${ }^{47}$ Godfrey is at another juncture in the Antioche used to vocalise praise of Robert of Flanders, asserting that he did not know 'anyone more noble in bearing arms' than Robert (Je ne sai plus praudome por ses armes porter). ${ }^{48}$ Similarly, at one point Godfrey addresses Robert of Normandy in the following terms: 'You are a noble count, a good man and brave with it' (Robert, jentius quens, frans hon, ciere hardie). ${ }^{49}$ In the Jérusalem, Godfrey addresses Robert of Flanders in terms that accentuate his qualities (Cosin, molt estes ber). ${ }^{50}$ When making a rousing speech to the rest of the crusading to encourage them before the assault upon Jerusalem, he addresses them as 'noble lords and brave knights' (gentius barnages! franc chevalier vaillant!). ${ }^{51}$

\footnotetext{
${ }^{45}$ ChJér, 165/282.

${ }^{46}$ ChAnt, 1.139/165.

${ }^{47}$ ChAnt, $1.175 / 180$.

${ }^{48}$ ChAnt, 1.302/246.

${ }^{49}$ ChAnt, 1.373/278.

${ }^{50}$ ChJér, 88/219

${ }^{51}$ ChJér, $137 / 259$.
} 
The Antioche and the Jérusalem place particular emphasis on Godfrey’s many talents and qualities as a man of war, both as a leader of men and as a warrior in his own right. A key characteristic of a leader in the chansons de geste was the ability to inspire his men. ${ }^{52}$ This no doubt informed the passages in which Godfrey is cast as an effective and energising general. At one point in the Jérusalem, he 'put heart into his men’ (Godefrois a se gent resbaudie) with his warcry. ${ }^{53}$ At one juncture in the Antioche, Godfrey exhorts the crusaders to fight their Turkish enemy, and they respond to him that they would follow him to the death. ${ }^{54}$ Ahead of another battle, Godfrey makes another exhortation to his men not to lose heart, prompting them to respond: 'My Lord, we shall do as you command....All of us would rather die than do anything shameful' (Sire, vostre commant feron,/ Miux volons tot morir que faire mesprison) ${ }^{55}$ At the end of the Antioche, when it is reported to the rest of the leaders that Godfrey had gone missing after the major battle outside Antioch, they are described as bursting into tears, before mounting a rescue mission: 'If we cannot get him back, we shall follow after him all the way to the kingdom of Persia' (Se nos nel retrovon/ Dusqu'el regne de Perse après lui en iron) ${ }^{56}$ In the Jérusalem, when the crusaders arrive at the Holy City, Thomas of La Fère outlines how the imperious fortifications of the city made it such a difficult military target, but asserted that 'by the loyalty I owe Godfrey of Bouillon and Our Lord whom I love and adore' (par le foi que doi Godefroi de Baiviere/ Et la nostre segnor qui jo ainm et tieng ciere) he would attack the city with all his might. ${ }^{57}$ Ahead of another battle in this song, Peter the Hermit affirms his personal commitment to Godfrey as follows: 'My lord,

\footnotetext{
${ }^{52}$ Noble, ‘Military Leadership’, pp. 181-2.

${ }^{53}$ ChJér, 164/281

${ }^{54}$ ChAnt, 1.299/244.

${ }^{55}$ ChAnt, 1.396/289.

${ }^{56}$ ChAnt, 1.455/317.

${ }^{57}$ ChJér, 60/194.
} 
I am going to take up arms too in recognition of the love I bear you' (Sire, por vostre amor serai jo armés ja). ${ }^{58}$ After Godfrey’s appointment as ‘king’ of Jerusalem, he makes a speech exhorting his men the day before they were to ride about to battle. The crusader forces offer the following reply: 'King Godfrey, our lord, you are our protector and not one of us will let you down even at the price of dismemberment. Every last one would rather have his head cut off than flee as much as four feet from the pagans' (Sire, rois Godefrois, tu iés nos avoués,/ Ja ne t'en faura uns por ester desmenbrés./ N'i a cel ne vausist mius fust ses ciés colpes/ K'il fuïst por paiens .IIII. pies mesurés). ${ }^{59}$

Noble's study of the qualities associated with military leaders in the chansons indicates that strategic sense was not as critical a characteristic as personal bravery. ${ }^{60}$ However, this is not to suggest that strategic sense was an insignificant quality for the chief protagonists. It is the case that the songs of the 'cycle rudimentaire' at certain points emphasise Godfrey had knowledge of military tactics. Hence, at one point in the Antioche, he is depicted instructing Stephen of Blois to lead a force to guard a mountain pass, while the Jérusalem has Godfrey drawing up the crusaders' battle lines ahead of their assault on the Holy City ${ }^{61}$ Moreover, Godfrey is held up as a shrewd tactician, a man who was capable of enacting elaborate tricks which effectively fooled the crusaders' enemies. At one juncture in the Jérusalem, the crusaders intercept carrier pigeons sent by the Muslim ruler of Jerusalem. The pigeons were carrying messages which requested other Muslim lords in the region to send reinforcements. Godfrey is ascribed with the idea of replacing the original messages with letters encouraging Muslim armies instead to stay away from the Holy City. ${ }^{62}$ Later on,

\footnotetext{
${ }^{58}$ ChJér, $185 / 298$.

${ }^{59}$ ChJér, 204/312.

${ }^{60}$ Noble, 'Military Leadership', pp. 182-9.

${ }^{61}$ ChAnt, 1.86-7/140; ChJér, 82-3/214-15.

${ }^{62}$ ChJér, 97-100/227-8.
} 
after his appointment as 'king', Godfrey originates an even more elaborate ruse designed to bolster the crusaders' chances while they were besieged inside the Holy City. The song states that Godfrey, a 'shrewd operator' (Godefrois fu hom de grant escïent) had each of his force of 20,500 men march past the enemy army ten times, changing their clothes after each pass. The song suggests that this 'remarkably cunning trick' (çou fu molt grans voisdie) successfully fooled the besieging army into thinking that the crusaders numbered far more than they actually did. ${ }^{63}$

The chansons de geste typically devote close attention to the items used by their heroes in warfare. Weapons (especially swords) and armour are often are described as exhibiting exquisite craftsmanship as well as having exotic and prestigious origins. As Hanley notes, these descriptions of arms and armour essentially function as self-contained narrative elements within the texts. ${ }^{64}$ Linked to this, the chansons regularly contain highly formulaic scenes in which the leading protagonists ritually arm themselves ahead of battle. The Jérusalem thus provides descriptions of Godfrey’s flag - ‘a dragon which had a diagonal pattern on its tail' (al tragon qui avoit la coue gironee) ${ }^{65}$ - and his tent. ${ }^{66}$ One arming scene in the Antioche recounts how Godfrey took up his hauberk and sword before mounting his Gascon warhorse. ${ }^{67}$ In another arming scene later on in the same song, Godfrey is aided by the otherwise unknown Antelm of Avignon (who laced his greaves for him), before donning his hauberk, his round helmet, his sword, and mounting his horse (on this occasion a steed from Carion) ${ }^{68}$ In one particularly crucial arming scene in the Antioche, Godfrey is assisted

\footnotetext{
${ }^{63}$ ChJér, 176/291.

${ }^{64}$ Hanley, War and Combat, pp. 147-51.

${ }^{65}$ ChJér, 208/314.

${ }^{66}$ ChJér, 117/243.

${ }^{67}$ ChAnt, 1.158/172.

${ }^{68}$ ChAnt, 1.199/191.
} 
in his pre-battle rituals by his brothers: '[Godfrey] put on his greaves and hauberk. Baldwin and Eustace laced up his helmet; then he buckled on his prized sword. Shield round his neck, he swung into Capalu’s saddle. There were four dragons on the flag he carried. Once [Godfrey] was armed he spurred his horse on so powerfully that it arched its back beneath him' (Il a caucié ses cauces, son auberc endossa./ Bauduïns et Wistases son elme le laça,/ Puis a çainte l'espee que molt forment ama./ Son escu a son col en Chapalu monta,/ En l'ensegne qu'il porte. IIII. dragons i a./ Quant li rois fu armés el ceval s’afiça/ Par issi grant vertu que sous lui arçoia). ${ }^{69}$

The significance of arms and armour in these songs is also attested by the passage in the Jérusalem in which the 'sultan of Persia' sends Godfrey a messenger on a fine white Aragonese horse, with a fine saddle and valuable decorated stirrups, in an effort to tempt and distract Godfrey, and thereby undermine his ability to fight. ${ }^{70}$ Godfrey, though, does not take the bait. It is also of note that the songs relate that Godfrey used a number of different horses throughout the crusade. In addition to the afore-mentioned Gascon warhorse and his steed from Carion, he variously rides an 'excellent Syrian mule' (del bon mul de Surie) ${ }^{71}$, an Arab warhorse, ${ }^{72}$ a Castilian horse, ${ }^{73}$ and a 'white horse from Alenie' (le blanc d'Alenie) ${ }^{74}$ Whilst these various mounts no doubt serve to perpetuate the rhyming scheme of the particular laisse in which they each appear, they nonetheless seek to convey the impression that Godfrey had a different horse for almost every military encounter.

\footnotetext{
${ }^{69}$ ChJér, 211/317.

${ }^{70}$ ChJér, 195-6/305-6.

${ }^{71}$ ChAnt, 1.373/279.

${ }^{72}$ ChAnt, 1.434/308.

${ }^{73}$ ChJér, 76/209.

${ }^{74}$ ChJér, 244/343.
} 
The songs also depict Godfrey as a man who was constantly thirsty for battle. Hence, in one passage in the Antioche, when the bishop of Le Puy asks Godfrey to carry the Holy Lance into battle, he refuses in the following terms: 'I would not carry it even if you were to give me all the gold in Russia. I am more interested in fighting the hated [Saracens]...I shall strike so many blows with my glittering sword that my entire fists will be blackened with [their] blood' (Sire...jo n'en porterai mie/ Se vos or me doniés tot l'or qui'st en Rosie./ Plus desir la bataille contre la gent haïe/...Tant i ferrai anqui de l'espee forbie/ Que trosqu'en mes poins ert de lor sanc ennoircie). ${ }^{75}$ In the same song, while the crusaders are taunted by the foe known as Brohadas at Antioch, Godfrey is said to have 'thought it inexcusable not to go and strike him' (se ferir ne la va, tient soi a mal bailli). ${ }^{76}$ In the Jérusalem, as the crusaders were preparing to make their assault on the Holy City, it is related that Godfrey 'did not hang back: he had the great horn blown aloud. This was a signal for those in the army to arm themselves’ (Godefrois...ne se vaut atargier,/ Le maistre cor a fait soner et grailloier./ Don't s'armerent par l'ost). ${ }^{77}$

More than anything else, the chansons de geste are concerned with recounting warfare itself. They have a particular focus on battles, and above all episodes of single combat between Christian heroes and their ‘pagan’ adversaries. These set-piece one-on-one encounters act as one of the principal mechanisms for conveying knightly heroism, as well as a narrative device for conveying battle scenes in the context of oral delivery. ${ }^{78}$ What elevates the heroes from the rest of the Christian protagonists in the chansons is the fact that they possess superhuman strength and skill, and above all the ability to inflict devastation upon the

\footnotetext{
${ }^{75}$ ChAnt, 1.386/284. The other leaders also make similar refusals to the bishop of Le Puy.

${ }^{76}$ ChAnt, $1.434 / 308$

${ }^{77}$ ChJér, $134 / 257$.

${ }^{78}$ Hanley, War and Combat, pp. 117-30.
} 
enemy lines - as well as individual foes - in combat. ${ }^{79}$ For this reason, particular attention is paid to Godfrey's talent with the sword in the 'cycle rudimentaire'. At one point in the Antioche, Godfrey stands guard alone during the night, and, after being attacked, is described as decapitating fourteen enemy warriors, with the rest of his comrades learning of his feat only when they rose from their beds the next morning. ${ }^{80}$ Later on in the song, he decapitates a foe named Soliman with his sword. ${ }^{81} \mathrm{He}$ is at one point described as being separated from the rest of the crusaders and fighting hordes of enemies on his own (a common plot device in the chansons). ${ }^{82}$ In that passage, he is described as wreaking havoc, with the narrator comparing him to other heroes of other cycles of chansons de geste: 'Anyone who could have seen [Godfrey] dismembering Saracens and sending one of top of another somersaulting dead to the ground would have had no need to invoke the memory of Bertrand [of Orange] or Aimeri [of Narbonne] (Ki don't veïst le prince Sarrasins desmembre,/ L'un mort deserure l'autre a terre trestorner,/ Por nïent ramentust Bertran ne Aïmer.) ${ }^{83}$ At another point, Godfrey strikes another unfortunate foe with such venom that he 'sliced his heart in two inside his chest' ( $\mathrm{La}$ cuer qu'il a el ventre li a parmi parti). ${ }^{84}$

One passage in the Jérusalem calls on its audience to imagine Godfrey 'dealing out death and destruction, cutting off the heads of more than 20,000 pagans' (Mais li dus de Buillon lor fu a l'encontrer. Illuec le veïssiés molt fierement capler,/ Plus de .XX.M. paiens

\footnotetext{
${ }^{79}$ Noble, ‘Military Leadership’, pp. 175-82.

${ }^{80}$ ChAnt, 1.157-8/172.

${ }^{81}$ ChAnt, 1.444/312.

${ }^{82}$ ChAnt, 1.453-5/315-16.

${ }^{83}$ ChAnt, 1.445/317.

${ }^{84}$ ChAnt, 1.434/308.
} 
fist les testes colper). ${ }^{85} \mathrm{~A}$ few laisses later, he is recounted as flinging himself into battle against a force of 60,000 Turks, again distinguishing himself:

Imagine him laying about him left, right and centre. I can tell you this for certain: he did not land one single blow which did not kill a Saracen or his horse. The ranks thinned in front of him no matter which way he turned. The Turks scattered in front of him like larks in front of a sparrowhawk, not daring to come near him...The Turks killed his horse beneath him. He leapt up from it, full of courage, grasping his shield and drawing his steel sword. Anyone who saw the lord slicing his way through Saracens, sending one staggering to his death on top of another one, could not have imagined a better knight (Dont veïssiés le roi bien ses cols emploier./ Onques n'I feri coup - bien le puis afficier - N'ocesist Sattasin, u lui u son destrier./ Quel part que li rois torne fait les rens claroier./ Autresi con l'aloë fuit devant l'esprevier/Vont li Turc entor lui: ne l'osent aproismier...Car Turc lu onto cis desous lui son destrier;/ Et li rois resaut sus, qui le corage ot fier,/ Il embrasce l'escu et trait le brant d'acier./ Ki veïst le baron Sarrasins destrenchier/ L'un mort desore l'autre abatre et trebucier,/ Por nient ramenteüst nul mellor chevalier). ${ }^{86}$

The heroes of the chansons de geste are regularly described as scything opponents in two with a single blow of their sword. Godfrey's ability to enact this feat is a recurring theme of both the Antioche and the Jérusalem. ${ }^{87}$ In an important sequence of laisses in the Antioche,

\footnotetext{
${ }^{85}$ ChJér, 139/261.

${ }^{86}$ ChJér, 166-7/283.

${ }^{87}$ On the ubiquity of the bisection feat in the chansons, and the various textual incarnations of Godfrey’s reputed feat, see: S. John, ““Claruit Ibi Multum Dux Lotharingiae”: The development of the epic tradition of
} 
he slices a number of enemies in two in quick succession. Firstly, he is recounted to have 'sliced a Turk in half right down to his lungs so that one half hung down on each side of the saddle (Tot en fendi un Turc desci que el pomon,/ Que le moitiés en pent d'ambes pars de l'arçon).$^{88}$ Shortly after that, in what might be intended as a recapitulation of the same feat, Godfrey is described as striking a 'Saracen' atop his helmet, 'slicing downwards so far into his vital organs that the two halves hung right down to ground level' (Tout le fendi le cors desci qu'en la coree,/ Que les motiés en pendent tot contreval la pree). ${ }^{89}$ Immediately after this, he encounters another unfortunate foe, this time mounted, whom 'he slashed straight through the spine so that one half [of the foe] fell to the ground while the other half stayed in the golden saddle, the body gripping tight though the soul had gone, with the leg stiff as if it had been fixed in position' (Tot le coupa li dus tres parmi l;eskinee,/ L'une moitiés des Turc caï emmi la pree,/ Et li autre est remise en la sele doree,/ Li cars del Turc s'estraint, car l'arme e nest alee,/ Si fu roide la jambe com s'ele fust plantee). ${ }^{90}$ This feat of swordsmanship is echoed in the Jérusalem. At one point in that song, Godfrey is described as cutting an opponent named Malargu in half through the chest. ${ }^{91}$ Soon afterwards, Godfrey agrees to enter single combat with a foe named Marbrin. Godfrey permits Marbrin to strike two blows before he himself retaliates. Though Godfrey is slightly wounded by Marbin's strikes, he is able to retaliate after the second. It is recounted that Godfrey swung his sword down 'as viciously as a wind in a storm and cut [Marbrin] in half all the way down to the felt pad of the saddle. God performed an extraordinary miracle because [Godfrey] cut the swift horse into

Godfrey of Bouillon and the Bisected Turk', in Simon Parsons and Linda Paterson (eds), The Literature of the Crusades (Woodbridge, 2018), pp. 7-24.

${ }^{88}$ ChAnt, 1.200-1/192.

${ }^{89}$ ChAnt, 1.201/192.

${ }^{90}$ ChAnt, 1.202, 193.

${ }^{91}$ ChJér, 189/301. 
two halves. He left horse and ride utterly destroyed on a hillock' (Si vait bruiant l'espee que vens encontré oré,/ Dusqu'en l'afeutreüre l'a fendu et coupé./ Çou fu molt grans miracle que Dex I a mostré,/ Car e[n] .II. motiés trence le destrier sejorné./ Tout abat en .I. mont et a jus craventé). ${ }^{92}$

In these songs, Godfrey’s superhuman ability as a warrior extends beyond his proficiency with the sword. Echoing the contemporary chroniclers’ references to Godfrey’s accomplishment with the crossbow, the Jérusalem recounts several feats of skill carried out by Godfrey with his bow. ${ }^{93}$ At one point, he unleashes an arrow from his 'strong, tautly strung bow' (Li dus tenoit.I. arc fort et roit et trainant), and killed three kites with just a single arrow; the onlooking crusaders regard the feat as an omen from God, while it instils fear into the hearts of their enemies. ${ }^{94} \mathrm{~A}$ few passages later, Godfrey is depicted using a Turkish bow effectively in the midst of battle. ${ }^{95}$ At another point, he is depicted riding his horse faster than a crossbow bolt could fly. ${ }^{96} \mathrm{He}$ is also depicted as possessing immense acuity in his hearing; at one point he and Tancred are described as hearing a battle on the other side of a nearby hill. ${ }^{97}$ It is also the case that the heroes of the chansons are able to sustain serious (and seemingly fatal) wounds and bear the resultant pain and yet be able to continue fighting. ${ }^{98}$ Thus in the Antioche, when Godfrey is fighting on his own after being separated from the rest of the crusaders, he is described as being hit by numerous arrows shot

\footnotetext{
${ }^{92}$ ChJér, 200/309.

${ }^{93}$ On Godfrey’s proficiency with the crossbow: John, Godfrey of Bouillon, pp. 56, 129, 162.

${ }^{94}$ ChJér, 67/201.

${ }^{95}$ ChJér, 85-6/217.

${ }^{96}$ ChJér, $122 / 247$

${ }^{97}$ ChAnt, 1.94/144.

${ }^{98}$ Noble, ‘Military Leadership’, p. 175.
} 
by the Turks, being wounded in the liver and lungs, and beginning to fear that he would die as a result. ${ }^{99}$

Personal piety is another crucial characteristic for the heroes of the chansons de geste. The leading protagonists must give their trust and faith to God, and possess a profound devotion to the Christian faith. ${ }^{100}$ Accordingly, the songs of the 'cycle rudimentaire' lay much emphasis on Godfrey's devotion to Christianity and his relationship with God. Hence at one point in the Antioche he is described as Godfrey 'who led our army in the name of Almighty God the Redeemer' (Qui nostre ost encounduist el non al raemant). ${ }^{101} \mathrm{~A}$ few passages later in that song, when Godfrey hears that other crusaders had captured the cities of Tarsus and Mamistra, he is depicted raising 'his hands to heaven and [thanking] Almighty God who suffered for us' (Quant Godefrois l'oï, s'en tent ses mains amon,/ Damedeu en gracie qui vint a passion). ${ }^{102}$ During the assault on Antioch, it is reported to Godfrey that the rest of the leaders had gone missing. Godfrey, presuming they had been killed, laments and asserts that if only he had been with them, he would have protected them: 'my faith is so strong that it would have been enough to prevent their deaths; I would have put paid to even 20,000 Turks' (Jo me fi tant en Deu qu'il n'I morroient mie,/ Si eüst ais des Turs .xx. mil tolu la vie). ${ }^{103}$ In the Jérusalem he is referred to at one point as 'Godfrey who places a profound trust in God' (Godefrois, qui en Diu molt se fie). ${ }^{104}$ When explaining to the other leaders outside Jerusalem how to set up the siege on the city, Godfrey beseeches them as follows: 'In

\footnotetext{
${ }^{99}$ ChAnt, 1.455-6/317. One might tentatively term this the 'Boromir effect'.

${ }^{100}$ Noble, 'Military Leadership’, p. 189.

${ }^{101}$ ChAnt, 1.114/155.

${ }^{102}$ ChAnt, 1.139/165.

${ }^{103}$ ChAnt, $1.312 / 250-1$.

${ }^{104}$ ChJér, 45/182.
} 
the name of God pay attention and I will explain how we can set about taking Jerusalem' (Or esgardés por Deu comment nos le feron,/ Par con faite maniere Jursalem asauron). ${ }^{105}$ At another point, Godfrey ‘swore by the Holy Sepulchre, where he hoped to worship’ (Et jure le Sepucre, qu'il vauroit aorer) that he would pursue his foe Cornumarant until he was able to kill him. ${ }^{106}$

As well as possessing a deep personal religious conviction, Godfrey is also repeatedly shown both calling for and receiving divine assistance in battle. In the Antioche, after severely inclement weather weakens their assault on Antioch, Godfrey assured his crusaders that God would intervene to aid the crusaders. ${ }^{107}$ At a later point in the song, Godfrey asks Christ directly for help to capture Antioch: 'Our glorious Lord and Father God, who allowed yourself to suffer on the Holy Cross for the salvation of your people, just as this is true which I believe to beyond question - please grant that tonight we may take the city' (Glorious sire pere qui le taisas pener/ En le saintime crois por ton pule salver,/ Diex, si com ce est voirs, et jel croi sans doubter,/ Si nos donés a nuit le cité conquester). ${ }^{108}$ Likewise, at the outset of the Jérusalem, Godfrey calls for divine assistance to improve the crusaders' position: 'Radiant redeeming Father and Holy Lady Mary, who carried within you the Saviour of the world, come to our aid now!' (Biaus pere raemans,/ Sainte Marie dame, qui portas en tes flans/ Le Salveor del mont, soiés nos hui aidans). ${ }^{109}$ At one point, he affirms to Robert of Flanders that the crusaders 'will take the [Jerusalem] at the pleasure of God and St Peter' (Se Deu plaist et saint Piere adonques le prendron). ${ }^{110}$ Crucially, Godfrey does not

\footnotetext{
${ }^{105}$ ChJér, 62/196.

${ }^{106}$ ChJér, 123/247.

${ }^{107}$ ChAnt, $1.191-2 / 187-8$.

${ }^{108}$ ChAnt, 1.302/246.

${ }^{109}$ ChJér, 38/176.

${ }^{110}$ ChJér, 116/242.
} 
only request divine assistance; at certain moments, he receives it. Hence, at one point in the Antioche he receives help in battle from Sts George and Demetrius. ${ }^{111}$ There is a direct echo of this in the Jérusalem, wherein it is recounted at one point that in the grand battle which took place after the capture of Jerusalem, Godfrey received divine assistance from Sts George, Maurice, Demetrius and others, who brought a force of over 300,000. ${ }^{112}$

In both songs, Godfrey is selected as a mouthpiece for the 'prière du plus grand péril'. These are staple element of chansons de geste, in which the knightly protagonists make an extended and heartfelt invocation to God. ${ }^{113}$ Near the end of the Antioche, Godfrey is separated from the rest of his comrades and fears death, prompting him to give the following prayer:

Glorious Lord God, you brought back the body of St Lazarus from the dead with your blessing. The beautiful Mary Magdalen came so close to you in the house of Simon and sat at your feet on a low couch; she poured out so many tears from the depth of her heart that she washed your feet with them all over, then anointed them with balm in the goodness of her heart. That was a very wise thing to do and she was well rewarded: you pardoned her all her sins. Lord, just as this is true - as we sincerely believe - just so please save my body from death and captivity and help me to avoid being overwhelmed by these wicked Saracens.

(Glorieus sire pere, par vo beneïçon/ De la mort surescistes le cors saint Lazaron;/ Marie Madeleine a le gente façon/S'aproisma tant de vos a le maison Simon/Qu'ele

\footnotetext{
111 ChAnt, 1.158/172.

112 ChJér, 166-7/283.

${ }^{113}$ On the nature of these prayers in general, see J. De Caluwé, 'La “prière épique” dans les plus ancien chansons de geste françaises', in Olifant, vol. 4, no. 1 (1976), 4-20.
} 
vint a vos pies ar desos un leson;/ Des larmes de son cuer fist tel sorversion/ Qu'ele les lava tos encoste et environ,/ Aprés les oint de mire par bone entention,/ Ele fist molt que sage, s'en ot bon gueredon,/ Car de tos ses peciés li festistes pardon./ Sire, si com c'est voirs, et noe bien le creon,/ Si garissiés mon cors de mort et de prison,/ Que vaincre ne me puissant cist Sarrasin felon). ${ }^{114}$

In this instance, Godfrey's prayer is answered, for his fellow crusaders soon arrive to rescue him in the nick of time. In a very similar scene in the Jérusalem - so similar that it is to all intents and purposes a rerun of the scene in the Antioche just discussed - Godfrey makes another appeal for divine assistance, again in the form of a 'prière du plus grand péril', as follows: 'Lord God Our Father...take pity on the little army of Your people which has remained here to guard Your city where You body suffered and the Holy Sepulchre in which You were laid' (Segnor...se vos plaist, entendés!/ Jou vos pri qu'il n’ait .I. seul tant soit osés/ Ki de la cite isse por cose que veés). ${ }^{115}$

This theme reaches its crescendo in the passage in the Jérusalem which recounts the circumstances in which Godfrey was chosen to be 'king' of Jerusalem. The song relates that the crusaders gathered in the Temple and beseeched God to indicate who should be granted the office. Then, at midnight, the crusaders are plunged into darkness, and there is a roll of thunder and a crash of lightning, which lights the previously unlit candle held by Godfrey, symbolising that he had been chosen by God to rule the Holy City. Godfrey promises to rule in Christ's name, and vouchsafes that he would give his life to protect the city if need be, prompting the rest of the crusaders to acclaim him: 'God has done a good day’s work today

\footnotetext{
${ }^{114}$ ChAnt, 1.456/317-18.

${ }^{115}$ ChJér, 183/296.
} 
in lighting his candle for you!' (Bien a hui Dex por vos se candelle alumee). ${ }^{116}$ Shortly before Godfrey’s divine selection as 'king' in the Jérusalem, the song foreshadows his appointment by casting him as the conduit through which a miracle was enacted. In the passage recounting how the crusaders overran the city, Godfrey, along with Robert of Flanders and Thomas of Marle is described as heading straight the church of the Holy Sepulchre, in order to begin cleaning it. Godfrey then encounters the warden of a nearby palace, and throws the silken cloth with which he had cleaned the sepulchre onto the man's face, to signal he would take the keeper into his protection. The man, who had been unable to see for thirty years, instantly had his sight restored. Upon hearing this, Godfrey gives thanks to God. ${ }^{117}$

Crucially, at points in these songs, the depiction of Godfrey moves beyond the emphasis on his personal piety and divine sponsorship. In several important passages, he is used as the mouthpiece for vocalising the aims of the First Crusade and the beliefs of its participants. Hence, at one point in the assault on Jerusalem, Godfrey explains to the rest of the crusaders why they sought the city: 'Here is the city where God suffered death and lived again' (Vés ici le cité u Dex ot mort et vie). ${ }^{118}$ At another point in the Jérusalem, when it seemed as though Peter the Hermit was close to death at the hands of the Turks, Godfrey spoke to encourage his men by telling them they were carrying out God's work: 'If you hold fast to your faith God will be your Defender: and if he comes to your aid you have nothing to fear' (Bone creance aiés, Dex ort vos avoués:/ Se il vos velt aidier ja ar vos douterés). ${ }^{119}$ Shortly after, he again speaks to his men, and affirms that they need not fear death on the that their spiritual rewards awaited them if they were killed: 'Happy the one who dies for God; he

\footnotetext{
${ }^{116}$ ChJér, 152/272.

${ }^{117}$ ChJér, 144-5/265.

${ }^{118}$ ChJér, 85/217.

${ }^{119}$ ChJér, 190/301.
} 
will be crowned in Heaven with the angels' (Cil qui por Deu morra ert molt bons eüres,/ Et ciel avoec les angeles ert ses ciés colpés). ${ }^{120}$ Shortly after this, an entire laisse is devoted to a prayer delivered by Godfrey directly to God, in which he shows a not inconsiderable understanding of Biblical history and theology, before requesting that God send him a signal that he would defeat his enemies. ${ }^{121}$

This essay has aimed to show how textual conventions of the chansons de geste played a key role in shaping how Godfrey of Bouillon was presented in the Chanson d'Antioche and in the Chanson de Jérusalem. It showed that, in line with how the heroes of the chansons are generally depicted, great emphasis is placed on Godfrey's noble character, reputation and lineage, on his talents as a man of war, and as a man who was devoted to the Christian faith. However, in closing, it is important to note that these different facets were of course connected. The characteristics and qualities attributed to him must have been intended to mutually strengthen each other to advance an overall picture of a profoundly pious, militarily accomplished and noble warrior. This synergy is apparent at certain points: hence, at, at one point in the Jérusalem, Godfrey invokes Charlemagne’s famous war cry, before calling for aid in way which emphasises the underlying religious motivation of the First Crusade: 'Montjoie! Help us, Holy Sepulchre! (Monjoie! Sains Sepcures, aïe!). ${ }^{122}$ In another passage, Godfrey speaks words directly to his sword that typify the different qualities: 'Sword...yet again I shall see you stained with the blood of dead Saracens. I shall go down fighting before I die if such be the pleasure of God and His mother, whose soul will be blessed' (Espee...encore vos verrai tainte/ De sanc Sarrasin dont la vie ert estainte./ Ançois

\footnotetext{
${ }^{120}$ ChJér, 204/312.

${ }^{121}$ ChJér, 205-7/313-14

${ }^{122}$ ChJér, 164/281.
} 
que jo i muire i ferai tele emainte,/ Se Deu plaist et sa mere, don't l'arme sere sainte). ${ }^{123}$ The incarnation of Godfrey in the Antioche and the Jérusalem, then, tells us less about the 'real' Godfrey than it does about how the aristocratic preoccupations of the chansons de geste shaped the transmission of his memory.

${ }^{123}$ ChJér, 184/297. 